\title{
Examining the measurement invariance of the teachers' sense of self-efficacy scale in terms of gender
}

\author{
Yıldız Burcu Doğan ${ }^{1}$, Hüseyin Akar², Mehmet Üstüner ${ }^{3}$ \\ ${ }^{1,2}$ Department of Educational Sciences, Kilis 7 Aralik University, Kilis, Turkey \\ ${ }^{3}$ Department of Educational Sciences, İnönü University, Malatya, Turkey
}

\begin{tabular}{l}
\hline Article Info \\
\hline Article history: \\
Received Feb 7, 2019 \\
Revised Mar 29, 2019 \\
Accepted Apr 17, 2019 \\
\hline
\end{tabular}

Keywords:

Gender

Measurement invariance

Self-efficacy

Teachers' sense

\begin{abstract}
The aim of this research was to analyze the measurement invariance of the "Teachers' Sense of Self-Efficacy Scale," developed by Tschannen-Moran and Hoy, and adapted into Turkish and Turkish culture by Çapa, Çakıroğlu and Sarkaya, with respect to gender. Turkish version of the scale consists of 24 items and 3 subscales. The scale measures pre-service teachers' and teachers' sense of and belief in self-efficacy for student engagement, classroom management and instructional strategies. Research revealed that the scale is being used by a myriad of researchers. The sample of this study consists of 267 female, 163 male pre-service teachers who participated in the Pedagogical Formation Certificate Traning at Inönü University in the 20172018 academic years. First of all, CFA was executed in order to confirm the validity of the scale's current structure for both genders which was confirmed based on the analysis results. Then, MGCFA was executed to analyze the scale's measurement invariance in terms of gender. The results of the MGCFA indicated that the scale has the measurement invariance with respect to gender at each of the stages of strict, metric, scalar and configural invariance.
\end{abstract}

Copyright $(2019$ Institute of Advanced Engineering and Science. All rights reserved.

\section{Corresponding Author:}

Hüseyin Akar,

Department of Educational Sciences,

Kilis 7 Aralik University,

Mehmet Sanlı District, Doğan Güreş Paşa Avenue, No: 134, Kilis, Turkey.

Email: huseyinakar@kilis.edu.tr

\section{INTRODUCTION}

Educational institutions are structures undertaking important tasks in terms of the economic, social and cultural development of nations. Qualified human resource need of countries is met by educational institutions. Educational institutions not only reveal and make effort to develop individuals' potential endowments but also endeavor to make individuals attain certain behaviors, attitudes, skills, values and habits cherished by the society. Without a shadow of a doubt, teachers play the most crucial part in the fulfilment of this function of the educational institutions [1]. Teachers not only have a strong and a lasting impact on the character development of each and every individual constituting a nation but also play a vital role in passing on the intellectual accumulation of knowledge, technical skills and culture from one generation to another [2]. In this regard, teachers are considered to be at the heart of school improvement efforts and the most crucial factor shaping students' learning and development [3]. Such an approach towards teachers brings the matter of teacher quality and competency into the forefront. To this end, a number of qualifications and competencies that need to be possessed by teachers have been suggested to ensure the success of education systems. According to Demirel [4], the qualifications the effective teachers need to have can be collected under two major headings: personal qualifications and professional qualifications. Being motivating, focusing on success and acting professionally constitute the personal qualifications while planning educational activities, using teaching methods and techniques, effective communication, classroom 
management, using time efficiently, assessing the teaching process and leading students are the professional qualifications that an effective teacher should have. However, teachers need to not only have but also be capable of demonstrating these qualifications. The most important concept of competency is the sense of self-efficacy.

Self-efficacy was introduced based on the Social Cognitive Learning Theory of Albert Bandura. Sense of self-efficacy is defined as a person's belief in their own capacity in identifying and exhibiting the pattern of behavior required attaining a specific goal [5]. It is considered the most important component of success in both positive psychology and Bandura's Social Cognitive Learning Theory. Sense of self-efficacy is a substantial factor in delivering a successful performance as well as has a determinant impact on an individual's ability of controlling their own emotions, thoughts and behaviors [6]. Being knowledgeable and skilled is often not enough to be able to accomplish a specific task. One also needs to believe and expect that she/he is able to accomplish it. Research revealed that those who believe they can succeed in fulfilling a task perform better than those who do not $[7,8]$. On the other hand, people who are suspicious about their selfefficacy linger around the scenarios in which they fail and overcoming this suspicion can be very challenging. On the contrary, individuals with a higher sense of self-efficacy are observed to set higher goals and work harder to succeed [5]. Self-efficacy belief is known to have a significant impact on such variables as responsibility for and desire of attaining goals, motivation, fighting against difficulties, analytic thinking, and being vulnerable to stress and depression [9].

Teacher self-efficacy denotes teachers' belief about their own knowledge, skills and abilities as educators and is closely related to the success of the teaching process [10]. Teachers' sense of self-efficacy is defined as their beliefs about their own skills of planning, organizing and implementing the activities that are required to attain some specific educational goals [11]. Teacher self-efficacy is a concept about teachers' belief in their own potential to fulfil their specific educational duties [12]. In other words, it is the teachers' belief or perception regarding the extent of their competency as to producing the desired learning outcomes even if they are dealing with unmotivated or problematic students [13]. Teachers' perception of their own knowledge, skills and experiences has an important role in overcoming the obstacles they encounter in their professional life [14]. Research shows that teachers' self-efficacy belief has significant impacts on teacher and student outputs. It also has a significant influence on teachers' commitment to school, job satisfaction, motives and attitudes towards the profession [13, 15-17]. Teachers with high sense of self-efficacy are observed to be more open to new ideas, to be more eager to use new teaching methods, to design and organize their classrooms better and to have a greater desire and willingness to teach [13, 18-20]. According to Schiver and Czerniak [21], teachers with a higher level of self-efficacy belief are inclined to adopt studentoriented approaches, thus, ensure student engagement and employ a research-based teaching strategy whereas teachers with low level of self-efficacy are inclined to adopt a teacher-oriented approach, teaching rather verbally [22, 23]. Morever, teachers' sense of self-efficacy is observed to be closely related to students' achievement and motivation [24]. In this regard, teachers' fulfilling their own duties effectively, students' success and, therefore, school's success can be said to depend on teachers' sense of self-efficacy. Thus, preservice teachers' and teachers' self-efficacy belief needs to be at the desired level for the sake of teaching process' quality. In this regard, accurately identifying pre-service teachers' and teachers' current self-efficacy belief is of great importance. To this end, Tschannen-Moran and Hoy [13] developed the Teachers' Sense of Self-Efficacy Scale, which was adapted into Turkish and Turkish culture by Çapa, Çakıroğlu and Sarıkaya [25]. Turkish version of the scale consists of 24 items and 3 subscales. The scale measures teachers' efficacy for student engagement, classroom management and instructional strategies. The literature review suggests that the Teachers' Sense of Self-Efficacy Scale which was adapted into Turkish by Çapa, Çakıroğlu and Sarıkaya [25] has been used in a myriad of studies so far [16, 17, 26-32]. A significant number of these studies attempted to identify the antecedents and consequences of teachers' self-efficacy belief. Some other studies, on the other hand, carried out a descriptive investigation on teachers' current sense of self-efficacy. No studies were found investigating whether the current structure of the scale, used in a lot of studies in Turkey, is the same for different sub-groups (gender, city, school type, etc.) A scale is created based on the assumption that "an instrument measures the same thing in each group in which it is implemented." However, it is indicated in the studies that the measurement results obtained from the groups in which the instrument was implemented may not have identical/equivalent psychometric properties [33]. In this regard, whether or not a scale, developed or adapted to measure a specific trait, provides measurement invariance for different sub-groups needs to be checked. Measurement invariance means revealing the intended trait without being affected by another trait of the individual. In other words, it is to investigate whether or not the properties of a scale are identical across different groups [34].

A measurement instrument's having the same constructs in more than one group means that the factor loadings of the items of the scale, the correlations between factors and the error variances are the same $[35,36]$. Measurement invariance is a prerequisite in the comparison of groups to ensure that such

Int. J. Eval. \& Res. Educ. Vol. 8, No. 2, June 2019: 213 - 220 
comparison is meaningful [36-38]. Therefore, testing the measurement invariance of scales does not mean coming up with a new measurement instrument. Examining the scales by means of these tests helps us understand whether the measurement instrument exhibits the same structure in the obtained measurement results. A measurement may yield different results due to the participants' having and expressing different traits, but it may be wrong to associate such differences merely with participants' responses or statements. The difference in the measurement results may well be stemming from the measurement instrument it self $[37,38,34]$.

Multi-group Confirmatory Factor Analysiss (MGCFA) is a method commonly used to measure the invariance in a structure [39-41]. Comparison of the scores across groups can be made by way of testing them at four separate stages named as configural, metric, scalar and strict invariance respectively which are tested through the MGCFA [39, 42].

Configural Invariance: It is the basic level of measurement invariance applications [43]. It is the indicator of the fact that the items measure the identical construct across groups and provides evidence to construct validity [40]. According to Kline [41] configural invariance requires the same measurement design solely across groups.

Metric invariance: In a psychological measurement instrument, metric invariance tests the rates at which the groups respond to the items in the same way. It is used to test the assumption that the strength degree of the relationship between the items and the constructs constituting the items, namely the factor loadings, is identical and invariant across groups [44-46]. According to Millsap and Olivera-Aguilar [47], metric invariance requires the same factor loadings across groups as well as configural invariance. Metric invariance is also referred to as weak factorial invariance. In cases the metric invariance cannot be provided, it can be claimed that the factors do not have the same significance across groups [48].

Scalar invariance: It is a strong invariance level across groups and requires not only metric invariance but also equivalence of factor variances and covariances. When scalar invariance is established, comparison of the differences amongst group means leads to important consequences [47]. The assumption that the constant in the regression equations created for the items making up the measurement instrument is invariant across groups is being tested. The comparison of latent constructs is meaningful because conceptual structure, structural association and error sources have the quality of being the same in subgroups [36]. This invariance requires identical starting points both in the metrics and in the measurement [40].

Strict invariance: Whether or not the error variances of the scale differ across groups is tested. Previous studies focused on the factor structure, factor loadings, and item invariants as well as required error variances to be the same [40]. Ensuring strict invariance causes not only the observed variable means but also the factorial differences and covariances across groups to be compared [48].

In addition, as the variance of the latent variable increases the item error variance increases as well. Strict invariance is generally not acquired in practice. Stages of measurement invariance are hierarchical. Therefore, the stages are considered respectively and if invariance cannot be provided at any stage, the next stage does not need to be investigated [42]. Table 1 shows the stages of measurement invariance.

Table 1. Stages of measurement invariance

\begin{tabular}{lll}
\hline \multicolumn{1}{c}{$\begin{array}{c}\text { Stages of Measurement } \\
\text { Invariance }\end{array}$} & \multicolumn{1}{c}{ Status of the Invariance } & \multicolumn{1}{c}{ Group Comparison } \\
\hline $\begin{array}{l}\text { Configural } \\
\text { Metric }\end{array}$ & $\begin{array}{l}\text { Item / factor groups } \\
\text { Item / factor groups and factor loadings }\end{array}$ & $\begin{array}{l}\text { Factor variances and covariances } \\
\text { Scalar }\end{array}$ \\
$\begin{array}{l}\text { Item / factor groups, factor loadings, item } \\
\text { invariants }\end{array}$ & $\begin{array}{l}\text { Factor variances and covariances, means of the } \\
\text { observed variables }\end{array}$ \\
Strict & Item / factor groups, factor loadings, item & $\begin{array}{l}\text { Factor variances and covariances, means of the } \\
\text { observed variables, means of variances and covariances }\end{array}$ \\
\hline
\end{tabular}

\section{METHOD}

The study group of this research consists of the pre-service teachers who participated in the "pedagogical formation certificate traning" at Inönü University, Faulty of Education in the 2017-2018 academic year. 430 of the 800 pre-service teachers enrolled in the pedagogic formation traning volunteered to participate in the study. $267(62.1 \%)$ of the participants were female while $163(37.9 \%)$ were male. Age average of the participants was 23 .

Teachers' Sense of Self-Efficacy Scale were used in data collection. Teachers' Sense of SelfEfficacy Scale was developed by Tschannen-Moran and Hoy [13]. The Scale was adapted into Turkish by Çapa, Çakıroğlu and Sarıkaya [25]. Teachers' Sense of Self-Efficacy Scale consists of 24 items and three subscales (student engagement- classroom management- instructional strategies). "Efficacy in student engagement" subscale is made up of items regarding how much the teachers can get the students believe they

Examining the measurement invariance of the teachers' sense of self-efficacy scale in ... (Hüseyin AKAR) 
can do well in schoolwork. "Efficacy in classroom management" subscale is related to how much the teachers can control undesirable behavior in the classroom. "Efficacy in instructional strategies" subscale consists of items concerning how much the teachers can use a variety of teaching and assessment strategies [25].

In their adaptation, Çapa, Çakıroğlu and Sarıkaya [25] calculated the internal consistency coefficients as .82 for the "efficiency in student engagement" subscale, .84 for the "efficiency in classroom management" subscale and .86 for the "efficiency in instructional strategies" subscale. Cronbach's alpha internal consistency coefficient was calculated to be .80 for the "efficiency in student engagement" subscale, 0.82 for the "efficiency in instructional strategies" subscale and .84 for the "efficiency in classroom management" subscale. The internal consistency coefficient was found to be .84 for the scale in general. The structure of the scale is as shown in Figure 1.

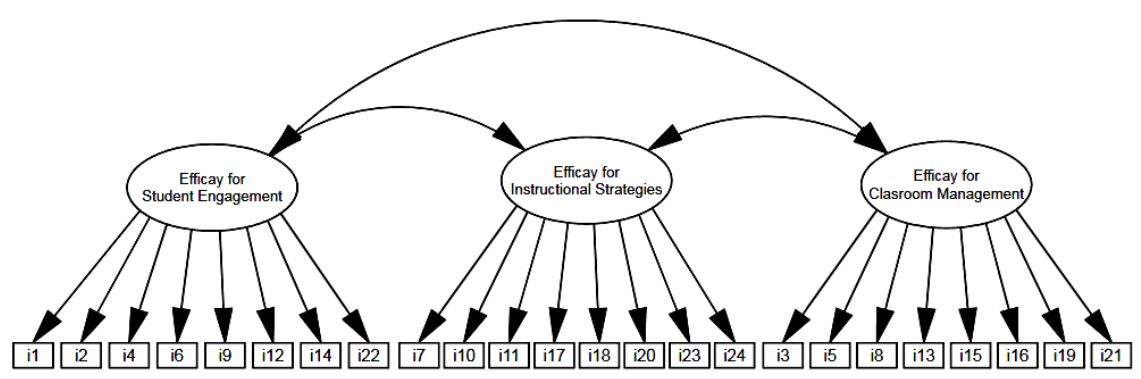

Figure 1. Structure of the teacher'sense of self-efficacy scale

\subsection{Data analysis}

SPSS 24.0 and LISREL 8.8 packaged programs were employed in the data analysis. SPSS was used to identify the distribution of data and to test the missing data, extreme value, normality and reliability coefficients. To perform confirmatory factor analysis on the Teachers' Sense of Self-Efficacy Scale and examine the measurement invariance across gender groups, LISREL 8.8 was used. The invariance of the model was analyzed by means of Multi Group Confirmatory Factor Analysiss (MGCFA) [35, 49-52]. To assess the model-data fit, $\chi^{2}, \chi^{2} / \mathrm{sd}$, RMSEA, CFI, NFI, IFI, NNFI model fit indices were adopted [53, 34]. RMSEA $<.08[54,55]$, CFI $>.90$, IFI $>.90$, NNFI $>.90[56,55]$ values were considered in the analysis of the confirmatory factor analysis results. In addition, RMSEA and SRMR values between .08 and .10 indicate an acceptable fit. If they are greater than .10, it indicates an unacceptable fit $[57,58,53]$. In the literature, $\chi^{2} / \mathrm{sd}$ rate indicates a perfect fit if it is below 3 and a mediocre fit if it is below 5 in the assessment of the confirmatory factor analysis results [59, 55]. To ensure accurate interpretation of the analysis results concerning the measurement invariance, first the missing values, extreme values and normality were taken into consideration. No missing data was detected. The variables were converted into scores (z) to identify the extreme values. For large sample groups $(n>100), z$ values outside the range of -3 to +3 are considered extreme values $[56,55]$. Based on the analysis results, 9 extreme values were excluded from the data set and analyses were performed on 430 persons. Kolmogorov-smirnov data showed that the data related to the three individual subscales showed a normal distribution by genders $(\mathrm{p}>.05)$.

\section{RESULTS}

In order to identify whether or not the measurement invariance was provided for the female and male groups of the "Teachers' Sense of Self-Efficacy Scale" by means of data obtained from the study group, first the CFA was performed on females and males separately, then MGCFA was executed. The CFA findings and fit values of the "Teachers' Sense of Self-Efficacy Scale" calculated for each individual female and male pre-service teacher are shown in Table 2.

Table 2. The CFA results and fit values of "Teachers' Sense of Self-Efficacy Scale" with respect to genders

\begin{tabular}{lllllllll}
\hline & $\chi 2$ & Sd & $\chi 2 /$ sd & RMSEA & CFI & NFI & IFI & NNFI \\
\hline Females & 659,82 & 249 & 2.65 & .077 & .95 & .91 & .95 & .94 \\
Males & 566.33 & 249 & 2.27 & .080 & .95 & .91 & .95 & .95 \\
\hline
\end{tabular}

Int. J. Eval. \& Res. Educ. Vol. 8, No. 2, June 2019: 213 - 220 
Examining Table 3, one can see that the fit values for the gender variable of the Teachers' Sense of Self-Efficacy Scale are within the acceptable range (RMSEA $<.08$, CFI $>.90$, IFI $>.90$, NNFI $>.90$ ). In addition, the fit indices resemble one another when the female and male groups are compared. In this regard, it can be stated that the current form of the "Teachers' Sense of Self-Efficacy Scale", consisting of 24 items and 3 subscales, has been confirmed for both female and male groups. Once the current structure of the scale was confirmed for both genders, investigation for the measurement invariance was initiated. The measurement invariance findings with respect to gender are as shown in Table 3.

Table 3. The measurement invariance results and fit values of the Teachers' Sense of Self-Efficacy Scale with

\begin{tabular}{llllllllll}
\multicolumn{10}{c}{ respect to gender } \\
\hline & $\chi 2$ & sd & $\chi 2 /$ sd & RMSEA[95\% CI $]$ & $\Delta$ RMSEA & SRMR & CFI & $\Delta$ CFI & NNFI \\
\hline Configural & 1262.86 & 525 & 2.40 & $.081[.075, .087]$ & - & .074 & .95 & - & .94 \\
Metric & 1254.01 & 523 & 2.40 & $.081[.075, .087]$ & .00 & .091 & .95 & .00 & .94 \\
Scale & 1253.88 & 525 & 2.39 & $.081[.075, .086]$ & .00 & .092 & .95 & .00 & .95 \\
Strict & 1292.30 & 549 & 2.35 & $.080[.074, .085]$ & .001 & .091 & .95 & .00 & .95 \\
\hline
\end{tabular}

Based on Table 3, it can be stated that the fit values of the model designed to test the configural invariance, which were used in the assessment of the model fit, are within the acceptable limits for gender $($ RMSEA $<.08$, CFI $>.90$, NNFI $>.90)$. Assessment of Chi-square and goodness of fit indices $\left(\chi^{2}=1262.86\right.$, $\left.\mathrm{sd}=525, \chi^{2} / \mathrm{sd}=2.40, \mathrm{CFI}=.95 ; \mathrm{RMSEA}=.081 ; \mathrm{NNFI}=.94\right)$ revealed that in both of the gender groups, a three-factor structure was present and configural invariance assumption was provided. Once the configural invariance was provided, the test proceeded to the next stage, the metric invariance.

Assessment of Chi-square and goodness of fit statistics $\left(\chi^{2}=1254.01, \mathrm{sd}=523, \chi^{2} / \mathrm{sd}=2.40 \mathrm{CFI}=\right.$ $.95, \mathrm{SRMR}=.091, \mathrm{RMSEA}=.081, \mathrm{NNFI}=.94)$ to test whether or not the factors present invariance at the metric invariance stage across groups reveals that the chi-square and goodness of fit values $(\chi 2 /$ sd $<3$ and $\Delta \mathrm{CFI}=.00)$ provided the metric invariance stage of the measurement model. Since the metric invariance was provided, the test proceeded to the next stage, the scalar invariance.

At the scalar invariance stage, the differences between the $\triangle \mathrm{CFI}$ and $\triangle \mathrm{RMSEA}$ values obtained from the metric invariance and $\triangle \mathrm{CFI}$ and $\triangle \mathrm{RMSEA}$ values obtained from the measurement invariance were assessed to test the scalar invariance. The findings revealed that the Teachers' Sense of Self-Efficacy Scale provided the scalar invariance of the measurement model $(\triangle \mathrm{CFI} \leq .01 ; \triangle \mathrm{RMSEA} \leq .015)$. The mean differences for the scale items can be said to stem from the latent variable means.

Assessment of the strict invariance model $\left(\chi^{2}=1292.30, \mathrm{sd}=525, \chi^{2} / \mathrm{sd}=2.35, \mathrm{CFI}=.95 ; \mathrm{SRMR}=\right.$ .091 ; RMSEA $=.080 ; \mathrm{NNFI}=.95)$ reveals that the measurement model provides the strict invariance stage $\left(\chi^{2} / \mathrm{sd}<3\right.$ and $\left.\triangle \mathrm{CFI}=.00\right)$.

In the light of the analyses, the model tested for the Teachers' Sense of Self-Efficacy Scale provided all of the invariance stages. Findings suggest that the measurement invariance is provided in the gender groups of the measurement model. In other words, the findings indicate that the Teachers' Sense of SelfEfficacy Scale has the measurement equivalence with respect to gender.

\section{CONCLUSION}

This study aimed to investigate the measurement invariance of the Teachers' Sense of Self-Efficacy Scale, developed by Tschannen-Moran and Hoy, adapted into Turkish by Çapa, Çakıroğlu and Sarıkaya and consisting of 24 items and 3 subscales, with respect to gender (female-male). To this end, several analyses were performed on the data obtained from 267 female and 163 male pre-service teachers.

CFA was carried out to confirm the 24-item and 3-subscale form of the scale for the female and male groups separately. Based on the CFA, the current form of the scale was confirmed for both the female and the male groups. Once the current structure of the scale was confirmed for each individual gender (female-male), MGCFA was executed to analyze the measurement invariance of the scale with respect to gender. MGCFA revealed that the Teachers' Sense of Self-Efficacy Scale has the measurement invariance with respect to gender. According to the results of the multi-group CFA, the current structure of the Teachers' Sense of Self-Efficacy Scale provided each of the metric, configural, strict invariance, scalar stages with respect to gender and thus fulfill the complete invariance requirement. In this regard, it can be said that the results obtained from the Teachers' Sense of Self-Efficacy Scale allowed for a comparison for the gender variable.

This study is of great importance in that it puts forward the fact that the Teachers' Sense of SelfEfficacy Scale has the measurement invariance, i.e. the measurement equivalence with respect to gender.

Examining the measurement invariance of the teachers' sense of self-efficacy scale in ... (Hüseyin AKAR) 
However, there are some limitations to it. The study was conducted based on the views of 430 pre-service teachers enrolled in the pedagogic formation certificate traning, which is considered to be a limitation. The analyses can be repeated with larger sample groups by including the pre-service teachers currently enrolled in the faculty of education to ensure the generalizability of the results. In addition, since the participation was on a voluntary basis and voluntary females outnumbered the males, the number of the male and the number of the female participants did not match, which is one of the important limitations.

\section{REFERENCES}

[1] Akar, H. "Meta-Analysis Study on Organizational Outcomes of Ethical Leadership," Educational Policy Analysis and Strategic Research, vol 13(4), pp. 6-25, 2018.

[2] Pani, D. "A study on quality of working life with special reference to private engineering college teachers in the District of Rayagada," Journal of Management and Science, vol 5(3), pp. 81-90, 2015

[3] İngersolli, R. "Is there really a teacher shortage? CPRE research reports," Retrieved from http://repository.upenn.edu/cpre_researchreports/37 (10.06.2016), 2003.

[4] Demirel, Ö. Planlamadan değerlendirmeye ögretme sanatı. Ankara: Pegem Akademi, 2000

[5] Bandura, A. Self-efficacy: The exercise of control (pp. 3-604). New York: wH Freeman, 1997.

[6] Halper, L. R. and Vancouver, J. B., "Self-efficacy's influence on persistence on a physical task: Moderating effect of performance feedback ambiguity," Psychology of Sport and Exercise, vol 22, pp. 170-177, 2016.

[7] Pajares, F. "Self-efficacy beliefs in academic settings," Review of Educational Research, vol 66(4), pp. 543-578, 1996.

[8] Jackson, J. W. "Enhancing self-efficacy and learning performance," The Journal of Experimental Education, vol 70(3), pp. 243-254, 2002.

[9] Bandura, A. Barbaranelli, C. Caprara, G. V. \& Pastorelli, C., "Multifaceted impact of self-efficacy beliefs on academic functioning," Child Development, vol 67(3), pp. 1206-1222, 1996.

[10] Gavora, P. "Slovak Pre-service Teacher Self-efficacy: Theoretical and Research Considerations," The New Educational Review, vol 21(2), pp. 17-30, 2010.

[11] Skaalvik, E. M. and Skaalvik, S., "Teacher self-efficacy and teacher burnout: A study of relations," Teaching and Teacher Education, vol 26(4), pp. 1059-1069, 2010.

[12] Pendergast, D. Garvis, S. \& Keogh, J., "Pre-service student-teacher self-efficacy beliefs: An insight into the making of teachers," Australian Journal of Teacher Education, vol 36(12), pp. 4, 2011.

[13] Tschannen-Moran, M. and Hoy, A. W., "Teacher efficacy: Capturing an elusive construct," Teaching and Teacher Education, vol 17(7), pp. 783-805, 2001.

[14] Savas, A. C. Bozgeyik, Y. \& Eser, İ., "A Study on the Relationship between Teacher Self Efficacy and Burnout," European Journal of Educational Research, vol 3(4), pp. 159-166, 2014.

[15] Evans, E. D. and Tribble M., "Perceived teaching problems, self-efficacy, and commitment to teaching among preservice teachers," The Journal of Educational Research, vol 80(2), pp. 81-85, 1986.

[16] Saracaloğlu, A. S. Karademir, Ç. A. Dinçer, B. \& Dedebali, N. C., "Öğretmenlerin Öğretme Stilleri, Özyeterlik ve İş Doyumlarının Belirlenmesi," Education Sciences, vol 12(1), pp. 58-85, 2017.

[17] Demirtaş, H. Cömert M. \& Özer, N., "Öğretmen adaylarının öğretmenlik mesleğine yönelik tutumları ile özyeterlik algıları arasındaki ilişki," Eğitim ve Bilim, vol 36(159), pp. 96-111, 2011.

[18] Allinder, R. "The relationship between efficacy and the instructional practices of special education teachers and consultants," Teacher Education and Special Education, vol 17, pp. 86-95, 1994.

[19] Cousins, J. B. and Walker, C. A., "Predictors of Educators' Valuing of Systematic Inquiry in Schools," Canadian Journal of Program Evaluation, vol 25, pp. 52, 2000.

[20] Coladarci, T. "Teachers' sense of efficacy and commitment to teaching," The Journal of Experimental Education, vol 60(4), pp. 323-337, 1992.

[21] Schriver, M. and Czerniak, C. M., "A comparison of middle and junior high science teachers' levels of efficacy and knowledge of developmentally appropriate curriculum and instruction," Journal of Science Teacher Education, vol 10(1), pp. 21-42, 1999.

[22] Aylar, F., and Aksin, A., "Sosyal bilgiler öğretmen adaylarının öz-yeterlilik inanç düzeyleri ve problem çözme becerileri üzerine bir araştırma (Amasya Örneği)," Ahi Evran Üniversitesi Kırşehir Eğitim Fakültesi Dergisi, vol 12(3), pp. 299-313, 2011.

[23] Arseven, A. "Öz yeterlilik: Bir kavram analizi." Electronic Turkish Studies, vol 11(19), pp. 63-80, 2016.

[24] Ashton, P. T. and Webb, R. B., Making a difference: Teachers' sense of efficacy and student achievement. Longman Publishing Group, 1986.

[25] Çapa, Y. Çakıroğlu, J. \& Sarıkaya H., "The development and validation of a Turkish version of teachers' sense of efficacy scale," Education and Science, vol 30(137), pp. 74-81, 2005.

[26] Üstüner, M. Demirtas, H. \& Cömert, M., "The attitudes of prospective teachers towards the profession of teaching (The case of Inonu University, Faculty of Education)," Eğitim ve Bilim, vol 34(151), pp. 140, 2009.

[27] Ekinci, H. "Öğretmen adaylarının özyeterlik algıları: resim, müzik ve beden eğitimi," Turkish Studies, vol 8(3), pp. 189-196, 2013

[28] Güvenç, H. "Sınıf öğretmenlerinin özerklik destekleri ve mesleki öz yeterlik algıları," Kuram ve Uygulamada Eğitim Yönetimi Dergisi, vol 17(1), pp. 99-116, 2011.

Int. J. Eval. \& Res. Educ. Vol. 8, No. 2, June 2019: 213 - 220 
[29] Kesicioğlu, O. S. and Güven, G., "Okul öncesi öğretmen adaylarının öz yeterlik düzeyleri ile problem çözme, empati ve iletişim becerileri arasındaki ilişkinin incelenmesi," Electronic Turkish Studies, vol 9(5), pp. 1371-1383, 2014.

[30] Ayra, M. and Kösterelioğlu, I., "The relationship between teachers' lifelong learning tendencies and their perceptions of professional self-efficacy," E-Journal of New World Sciences Academy, vol 10, pp. 17-28, 2015.

[31] Bümen, N. T. and Ercan Özaydın, T., "Adaylıktan göreve öğretmen özyeterliği ve öğretmenlik mesleğine yönelik tutumlardaki değişimler," Eğitim ve Bilim Dergisi, vol 38(169), pp. 109-124, 2013.

[32] Korkut K., and Babaoğlan, E., "Sınıf öğretmenlerinin öz yeterlik inançları," Uluslararası Yönetim İktisat ve İşletme Dergisi, vol 8(16), pp. 269-281, 2012.

[33] Başusta, N. B. and Gelbal, S., "Gruplararası karşılaştırmalarda ölçme değişmezliğinin test edilmesi: PISA öğrenci anketi örneği," Hacettepe Üniversitesi Ĕ̌itim Fakültesi Dergisi, vol 30(4), pp. 80-90, 2015.

[34] Karaduman, B. and Kilmen, S., "Sınav Stresi Ölçeğinin Türkçeye Uyarlanması ve Ölçme Değişmezliğinin Incelenmesi Adaptation of the Examination Stress Scale into Turkish and Examination of Measurement Invariance," Journal of Measurement and Evaluation in Education and Psychology, vol 9(2), pp. 101-115, 2018.

[35] Byrne, B. M. Multivariate applications book series. Structural equation modeling with LISREL, PRELIS, and SIMPLIS: Basic concepts, applications, and programming. Mahwah, NJ, US: Lawrence Erlbaum Associates Publishers, 1998.

[36] Uzun, B. and Öğretmen, T., "Fen Başarısı ile İlgili Bazi Değişkenlerin TIMMS-R Türkiye Örnekleminde Cinsiyete Göre Ölçme Değişmezliğinin Değerlendirilmesi," Eğitim ve Bilim, vol 155, pp. 26-35, 2010.

[37] Bollen, K. A. "A new incremental fit index for general structural equation models." Sociological Methods \& Research, vol 17(3), pp. 303-316, 1989.

[38] Cheung, G. W. and Rensvold, R. B., "Assessing extreme and acquiescence response sets in cross-cultural research using structural equations modeling," Journal of Cross-Cultural Psychology, vol 31(2), pp. 187-212, 2000.

[39] Widaman, K. F. and Reise, S. P., Exploring the measurement invariance of psychological instruments: Applications in the substance use domain. Ariel, 165, 220-14, 1997.

[40] Vandenberg, R. J. and Lance, C. E.,"A review and synthesis of the measurement invariance literature: Suggestions, practices, and recommendations for organizational research," Organizational Research Methods, vol 3(1), pp. 4-70, 2000.

[41] Kline, R. B. Convergence of structural equation modeling and multilevel modeling. In M. Williams (Ed.), Handbook of methodological innovation. Thousand Oaks, CA: Sage, 2011.

[42] Uysal, N. K. and Arıkan, Ç. A., "Measurement Invariance of Science Self-Efficacy Scale in PISA," International Journal of Assessment Tools in Education, vol 5(2), pp. 325-338, 2018.

[43] Wu, A. D. Li Z. \& Zumbo, B. D., "Decoding the meaning of factorial invariance and updating the practice of multigroup confirmatory factor analysis: A demonstration with TIMSS data," Practical Assessment, Research \& Evaluation, vol 12(3), pp. 1-26, 2007.

[44] Milfont, T. L. and Fischer, R., "Testing measurement invariance across groups: Applications in cross-cultural research," International Journal of Psychological Research, vol 3(1), pp. 111-130, 2010.

[45] Salzberger, T. Sinkovics, R. R. \& Schlegelmilch, B. B., "Data equivalence in cross-cultural research: A comparison of classical test theory and latent trait theory based approaches," Australasian Marketing Journal (AMJ), vol 7(2), pp. 23-38, 1999.

[46] Byrne, B. M. and Watkins, D., "The issue of measurement invariance revisited," Journal of Cross-Cultural Psychology, vol 34(2), pp. 155-175, 2003.

[47] Millsap, R. E. and Olivera-Aguilar, M., Investigating measurement invariance using confirmatory factor analysis. In R. H. Hoyle (Ed.), "Handbook of structural equation modeling (pp. 380-392). New York, NY, US: The Guilford Press, 2012.

[48] Gregorich, S. E. "Do self-report instruments allow meaningful comparisons across diverse population groups? Testing measurement invariance using the confirmatory factor analysis framework," Medical Care, vol 44 (11 Suppl 3), pp. 78, 2006.

[49] Jöreskog, K. G. and Sörbom, D., LISREL 8: User's guide. Chicago: Scientific Software, 1993.

[50] Schumacker, R. E. and Lomax, R. G., A Beginner's Guide to Structural Equation Modeling, Psychology Press, 2004.

[51] Raykov T., and Marcoulides G. A., "On multilevel model reliability estimation from the perspective of structural equation modeling," Structural Equation Modeling, vol 13(1), pp. 130-141, 2006.

[52] Uyar, Ş. and Doğan, N., "PISA 2009 Türkiye Örnekleminde Öğrenme Stratejileri Modelinin Farklı Gruplarda Ölçme Değişmezliğinin İncelenmesi," Uluslararası Türk Ĕ̆itim Bilimleri Dergisi, vol 2014(3), pp. 30-43, 2014.

[53] Hu, L. T. and Bentler, P. M,. "Cutoff criteria for fit indexes in covariance structure analysis: Conventional criteria versus new alternatives," Structural Equation Modeling: A Multidisciplinary Journal, vol 6(1), pp. 1-55, 1999.

[54] Hooper, D, Coughlan, J. \& Mullen, M. R., "Structural Equation Modelling: Guidelines for Determining Model Fit," Electronic Journal of Business Research Methods, vol 6(1), 2008.

[55] Çokluk, Ö., Şekercioğlu, G. \& ve Büyüköztürk, Ş. Sosyal bilimler için çok değişsenli istatistik SPSS ve LISREL uygulamaları. Ankara: Pegem Akademi, 2018.

[56] Tabachnick, B. G. and Fidell, L. S., Using multivariate statistics (6th ed.). New Jersey: Pearson, 2012.

[57] Kaplan, D. Structural equation modeling: foundations and extensions, Thousand Oakes, CA: Sage (Advanced Quantitative Techniques in the Social Sciences Series: Vol. 10), 2000. 
[58] Schermelleh-Engel, K., Moosbrugger, H., \& Müller, H., "Evaluating the fit of structural equation models: Tests of significance and descriptive goodness-of-fit measures," Methods of Psychological Research Online, vol 8(2), pp. 23-74, 2003.

[59] Sümer, N., "Yapısal eşitlik modelleri: Temel kavramlar ve örnek uygulamalar," Türk Psikoloji Yazıları, vol 3(6), pp. 49-74, 2000.

\section{BIOGRAPHIES OF AUTHORS}

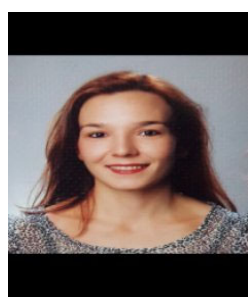

PhD student Yildız Burcu DOĞAN is a Lecturer attached to the Muallim Rifat Faculty of Education at Kilis 7 Aralı University in the Department of Guidance and Psychological Counseling. Her research and publication interests include topics such as social entrepreneurship, personal values, self-handicapping, self-efficacy, teacher training etc. She has presented papers at national and international congresses and published articles in various journals.

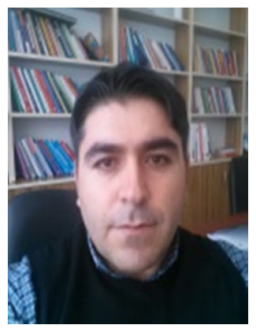

Dr. Hüseyin AKAR is an Assistant Professor attached to the Muallim Rifat Faculty of Education at Kilis 7 Aralık University in the Department of Educational Administration. His research and publication interests include topics such as quality of work life, educational administration, social entrepreneurship, teacher training, organizational behavior, and leadership. He has presented papers at national and international congresses and published articles in various journals.

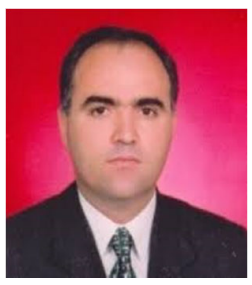

Dr. Mehmet Üstüner is a Professor (Full) attached to the Faculty of Education at İnönü University in the Department of Educational Administration. His research and publication interests include topics such as organizational behavior, quality of work life, social entrepreneurship, educational administration, organizational psychology, teacher training, attitudes, group dynamics etc. He has presented papers at national and international congresses and published articles in various journals. 